\title{
A Review on Social Responsibilities of Media from the Report of "Sanlu Problematic Milk Powder Incident"
}

\author{
Haifei Yu \\ Institute of Politics and Laws \\ Ludong University, Yantai 264025, China \\ Chengliang Zhang \\ Propaganda Department \\ Ludong University, Yantai 264025, China \\ E-mail: gongge_zhang@sina.com
}

\begin{abstract}
In an open and developed society, functions of media continue to spread, and their social responsibilities are also on the increase. As the social watcher and environmental monitor, how they should accomplish the historical mission endowed by the society in the presence of significant public and social issues? In this paper, taking the incident of "Sanlu problematic milk powder" as an example, the authors will discuss the social responsibilities of media in this incident.
\end{abstract}

Keywords: Sanlu problematic milk powder, Some brand, Mainstream media

Social functions of media determine that they should assume some social responsibilities. Whether from the perspective of historical development or realistic demands, social responsibility has already become one of "important factors" in news media's standardization of their occupation. As the "social watcher", in practical activities of news report, media have always been the "important content" in the emphasis on news authenticity, the requirement for leading of public opinion, and the focus on public opinion supervision, etc. However, there also exist some problems, which are displayed in deficiency of social responsibilities in report of particular public incidents. The significant safety incident of "Sanlu baby formula" which happened in September 2008 was exactly a typical case for discussion of media's social responsibilities. During this incident, media referred to Sanlu milk powder with an opaque "some brand". This caused social psychological confusion and public psychological anxiety, which deserves deep reflection of media practitioners. As a matter of fact, under the circumstance of psychological anxiety due to unclear truth and information, the individual sense tends to be beclouded by "hearsay", which might influence correct direction of public opinions.

\section{Production process of public opinion in the incident of "Sanlu problematic milk powder"}

On September $9^{\text {th }}$, "Lanzhou Morning Post" published a report entitled " 14 infants having suffered from nephrolith, which is caused by the similar brand of milk powder?". This report which involves foodstuff safety has astounded the whole country. All domestic media began to transload this news in succession, and community forums of all websites also concentrated on this paroxysmal public sanitation incident. Four days later, Office of the State Council held a news conference, in which was discussed the disposal issue on the significant safety incident of Sanlu milk powder. At the same time, the Central Committee of CPC and the State Council started up Class I responding mechanism of the national significant foodstuff safety incident, and a leading group of emergency was organized. The whole society switches the focus to the originator of "some brand" of milk powder --- Sanlu Group. Afterwards, the number issued by the government indicated that, from $12^{\text {th }}$ September to $17^{\text {th }}$, there were altogether 6244 diagnosed baby sufferers because of taking Sanlu milk powder, among which 158 suffered from acute rental failure. Besides, retrospective surveys have discovered 3 death babies.

It should be admitted that, in the production of public opinions in the significant safety issues of "Sanlu problematic milk powder" media have played an important role. However, a majority of media used such words as "some brand of milk powder", "the same milk powder" etc, in consideration of legal responsibility. This kind of "conservative" 
reporting has aroused anxiety and fear in the public that caused public opinion uproariousness, which, together with this paroxysmal public sanitation incident, rapidly fermented and formed a huge public opinion whirlpool of anxiety about "some brand". A search in relative reports from September $10^{\text {th }}$ to $12^{\text {th }}$ could tell us that, there are altogether 27100 articles with the keyword of "milk powder of some brand" on Baidu, among which are placed initially such pop articles as "What some brand refers to", "Please issue the "some brand' in name of life of children", "Gansu nephrolith milk powder! Whether should 'some brand' be issued or not". In the chain responses of public opinions resulted from "some brand", mainstream media and Internet have displayed different situations:

\subsection{Mainstream media - from conservative apprehensions to peripherization}

In the incident of "Sanlu problematic milk powder", what the mainstream media primarily adopted was a reporting strategy of conservation and meticulousness. Except for the first attack on public opinions initiated, most of them made "impersonal reactions" following the official steps.

The first phase: some local media adopted viewpoints of Ministry of Health, and partially called into question "milk powder of some brand".

On August $28^{\text {th }}$ and $29^{\text {th }}$, "Changjiang Times" published in succession articles entitled " 3 infants with the same disease, is the baby milk powder the prime criminal?", "the same milk powder and the same disease, other provinces also have such a case", in which three babies from different provinces were reported, who suffered from the same disease -- acute postrenal ischuria. The symptom of anuria came to them successively, which endangered their lives! Since the three children had been taking milk powder of the same brand, their parents doubted that, "it was most likely milk powder of this brand that caused the disease of these children." Afterwards, the similar situation also happened in Weifang of Shandong, Lanzhou of Gansu, Anhui and Hunan, etc,. Health experts expressed when interviewed, "if this was caused by milk powder, then it might be that the content of calcium was too high". This conclusion caused the incident of "Sanlu problematic milk powder" not able to produce public opinions at the first moment. Although doubts about "milk powder of some brand" on the Internet had begun to heat up, still feedback information didn't arouse further attention from the media.

The second phase: the media generated concentrative doubts about milk powder of "some brand", and public opinions of "Sanlu problematic milk powder" took the initial shape.

On September $9^{\text {th }}$, "Lanzhou Morning Post" published an article entitled "14 infants having suffered from nephrolith, which is caused by the similar brand of milk powder?" Immediately after publication, this article aroused attention in China, and some domestic media all transloaded this article, including Xinhua News Agency. While among all reports transloaded, a majority of media, without exception, used such words as "milk powder of some brand", and "milk powder os the same brand", except few media, such as Oriental Morning Post.

The third phase: taking authoritative information and positive report as the center.

Since September $13^{\text {th }}$, Ministry of Health and the government in Hebei Province has held news conference on "disposal work of significant safety incident of Sanlu milk powder", and a great deal of official news about "Sanlu problematic milk powder began to emerge in a variety of mainstream media. For instance, "it was initially believed that law breakers had added melamine into original milk" (September 13" ), "the State Council started up Class I responding mechanism of the national significant foodstuff safety incident" (September $14^{\text {th }}$ ), "phasic examination result issue of special examination on melamine in baby formula" (September $17^{\text {th }}$ ), and "result issue of special examination on melamine in liquid milk nationwide" (September $19^{\text {th }}$ ). All these reports have adopted information provided by the government. Although these reports had brought relative information to the public in anxiety, the force generated was not enough since they were incapable of playing the role of a strong medium to have impact on public opinions.

\subsection{Internet - from active participation to production of leading of public opinions}

In the incident of "Sanlu problematic milk powder", the Internet has always been concentrating on the progress of it with an active attitude. Most audiences participated in its discussion by means of the Internet, and finally, a force of public opinions that couldn't be neglected came into being.

The first phase: the Internet doubted about the parlance of "milk powder of some brand", and an intense dissatisfaction with dilemma of the mainstream media was caused, which resulted from anxiety in the public.

Since May 2008, individual posts about "Kidney Stones babies" have appeared on the Internet, which didn't arouse attention from the public. On August $28^{\text {th }}$, after the publication of the article "Is baby milk powder the prime criminal?" by "Changjiang Times", "Red Kid forum" posted an article entitled "infants suffered from ischuria, which was doubted to be related to milk powder of some brand. Victimization!" on the same day. Within three hours after the post was posted, it had been read 1230 times, and altogether 47 responding items. What most of the responding items concentrated on was what on earth "milk powder of some brand" exactly referred to. 
With intervention of mainstream media, and dilemma of the media due to legal consideration, the public immediately felt that their rights of information were disregarded. Therefore, their anxiety about "milk powder" was logically transferred to anxiety about the media, and a crack between the media and the public came into existence. The message by the net friend Qiqi from Wuhan reflected dissatisfaction of the public, "I feel that the media nowadays make us speechless. If they are not sure about a piece of news, they should publish it. If they publish it, then they can't make that clear, which, on the contrary, will cause worry among the public. We really can't understand where their logic lies in..." Owing to the Internet, dissatisfaction and anxiety of the public concentratively broke out. And under the promotion of each Internet forum, a whirlpool of public opinions in the doubt about "some brand" rapidly came into being.

The second phase: public relations in crisis in Sanlu incident were doubted, and the "Matthew Effect" was formed in the process of Internet transmission.

After the central committee of CPC and the State Council started up Class I responding mechanism of the national significant foodstuff safety incident, the Internet followed up directly the mainstream media. At the time when focusing on progress of the incident, several posts emerged on the Internet, such as "Five doubts about Sanlu declaration", "Mystical public relations letter in Sanlu", "The more one tries to cover up, the better-known it will become. Four boxes of milk powder sealed the mouth of consumers", and "To search who is the advertising spokesperson of Sanlu". A new Internet attack of public opinions on the incident of "Sanlu problematic milk powder" came into being.

The American scholar Robert K.Merton summarized the "Matthew Effect" as: for any individual, group, or district, once they accomplish greater success and progress, then an accumulative advantage will be generated, which might leave more opportunities for more success and progress. The "Matthew Effect" which is formed by voluntary participation of net citizen tends to produce pressure of public opinions on all parties related to the incident in the real world, and compels them to pay more attention to this incident. In the incident of "Sanlu problematic milk powder", public opinions formed on the Internet impelled progress of the incident.

\section{Analysis on attitude of media reporting}

To explore reasons for meticulous report of "some brand" by the media, there are three possibilities: firstly, the Ministry of Health which provided the news clue didn't offer specific brand information of milk powder; secondly, the media did this on purpose; thirdly, the parties involved communicated with the media through the public relations in crisis. In the first news of "Lanzhou Morning Post", there was such a report, "It is reported that, milk powder with a retail price of $¥ 18 / 400 \mathrm{~g}$ sells good, and has almost become the first choice of the parents for their new arrivals in rural areas." This proved that, after an interview with health experts, the reporters investigated the sale condition of the milk powder, which indicated that, staffers were clear about the brand information of the milk powder. In the article of "Sanlu Group sent its personnel to make clear the situation, and Huiyou Milk Powder stopped production in July" published in September $11^{\text {th }}$ by "Lanzhou Morning Post", they completely cited words of Sanlu personnel as the keynote of their report, and personnel from Sanlu Group ensured that there was no problem with the quality of the milk powder. From this, it can be concluded that, it was after the report in September $9^{\text {th }}$ that the public relations in crisis in Sanlu Group started and played their role. There was no close relation between the report on the milk powder of "some brand" and the activities of the public relations in crisis. Therefore, it can be understood that, the media behaved intentionally in this incident.

2.1 The enterprise involved in the incident is a well-known brand, so the media hesitated in the judgment on the news value and social influence without definite evidence and legal guarantee.

In the earlier news report, the majority of media tried to escape from the risk: even in the case when they knew very well that Sanlu was suspectable, they still didn't point out bluntly, and called hazily "milk powder of some brand". This, without doubt, is the most fatal smoke shell. In face of a well-known brand, the apprehension of the media is understandable. Without relative legal guarantee at present, the earlier reports on "milk powder of some brand" were mostly limited to provincial and city media, and other media couldn't verify it within a short period of time, it was impossible for the media concerned in the supervision on public opinions to obtain equipotent say with the supervised targets. Furthermore, local media which firstly reported the news might assume the legal risk of mistakenly reporting: if their report hadn't raised any tide of public opinions, it would be obvious that the local media couldn't bear censure from the well-known brand and their legal .inquisition.

Among some existing significant public incident cases in China, their transmission was quite similar, namely: initiation by media in different districts, formation of media news resource, transloading or reporting by media at a national class, then a final public opinion. For instance, the 'Nantong 7·17 Water Inrush Incident' in 2001" (Guangxin TV Station firstly reported), "Tongguan Incident" in 2006 (Henan Business Daily firstly reported), and "Shanxi Shady Brick Kiln" incident in 2007 (Henan TV Station City Channel firstly reported), etc, which all adopted this kind of report mode. It indicates that, currently, influential force of local media in China is not as is said, and they can't arouse a tide of public 
opinions immediately. Reports on significant incidents still depend on transloading of other media and following up of the media at a national class. In case that reporting of media in other districts didn't arouse a social influence and attention as expected, and other media didn't follow up and report, then they could have no choice but to independently assume all responsibilities looked into by the other party for their reporting "inconsistent with the facts", which, with no doubt, is too much for local media. Therefore, the first choice for public opinion supervision of local media is to select a stable supervision method and to report significant public safety incidents with a fuzzy tone so as to wait for other media to follow up and report.

\subsection{This incident might be upgraded into a public health safety incident, so the media left foreshadowing for successive reports.}

The content this incident involved is significant, so attention and influences from the society were obvious, which could arouse concentration from the society. Appropriate suspense might appeal to audiences, which will have a "white" effect on successive reports. As a matter of fact, whether "Changjiang Times" or "Lanzhou Morning Post", they both published successive reports, but only that, in consideration of avoiding risks, the former let pass this incident with a conclusion by experts that "maybe the content of calcium was too high", while the latter overthrew the topic preset in the previous report with help of negation by Sanlu Group. Among the current city-kind planar media, reporting on the same incident has been a customary reporting means. Their target is to presuppose suspense, and to enhance attention degree of the media. In view of reporting means by the media in the "Sanlu problematic milk powder incident", the first article by "Lanzhou Morning Post" presupposed suspense of "milk powder of some brand". In the following, they reported, "The Provincial Health Office has unfolded an investigation", and "Sanlu Group sent their personnel to go to Lanzhou to make clear the situation, and Huiyou Milk Powder has stopped production since July". Their reporting gradually pushed the party involved, namely Sanlu Group, in the presence of the audiences. From the perspective of news profession, this sort of reporting is, without doubt, successful, while it obvious hasn't put "interests of the public" in the first place from the perspective of responsibility on the society and on lives of the public.

\section{The mainstream media should assume alert responsibility for social paroxysmal public incidents.}

For the time being, in an era of globalized media with coexistence of new and out-of-date media, the fact that news is transmitted from multiple resources has been facing all the media unavoidably. Compared with other ideology criteria, public opinions about news have the characteristics of being non-forcible, subtle, and particularly flexible, which can play their part step by step in the socialization process. Therefore, public opinion leading of news media is extremely important. From the professional perspective of media, the media, the media have the feature of possessing public instrument, act as the "watcher" of the society, and hold the position of surveillant and promulgator of the social environmental information. In the presence of significant paroxysmal public health incidents, media, especially mainstream media should assume a compelling alert obligation. In reporting of significant incident that is concerned about public health and safety, preference of injustice to overindulge is supposed to be a fundamental standard for establishment of alert system by the media, which doesn't refer to impudent and inculpable framing, but refers to necessary countermeasures that the media should adopt based on significant social health incident with the principle of life being supreme.

Under the principle of realistic legal risk consideration and avoidance, and under the circumstance without definite evidence, the mainstream media have presented a meticulous attitude in the incident. In Hebei Province which was most seriously influenced, local media even escaped from the incident at the earlier period. Even the following reports, they also kept a relatively official standpoint as a whole. From the perspective of social alert responsibility, it's not that "Sanlu Milk Powder" can't be mentioned absolutely, but the key is how to mention. As long as the media impersonally report the facts calmly, accurately and skillfully, there is no means that "Sanlu Milk Powder" can cause reporting taboo. The fact that the relative media automatically gave up the right to report without outside interference indeed disappointed the public. So the public have reason to express rage against this, and the credit of media in the public is thereby impacted.

Considering the reporting strategy of media in the incident of milk powder of "some brand", it is suggested that, media should have sufficient psychological preparation and responding plan in the reporting of significant paroxysmal incidents. At present, domestic media, all without exception, handle each incident as a single case, and they haven't established an effective news reporting framework. In the situation when there is no presupposed news framework, reporters have no choice but to judge the value of each piece of news and its social influence according to their experiences. As for disputable news, its social influence is affirmatively higher than its value. Under this circumstance, judge on social value of relative information seems especially important. Therefore, how to make response to significant social issues and how to effectively resolve them, should not only be highly concentrated by relative Party and governmental sections, but should be vigorously explored by media in their unfolding supervision on public opinions. Only that the media assume the social responsibilities that they should, can they walk up to maturity in the competition of globalized media, build up perfect credit and influence in the public, and stand out in an environment of news 
transmission competition of multiple resources.

\section{References}

Dong, Tiance \& Liu, Wei. (2008). How to Conduct Public Opinion Supervision on Significant Social Issues. Journal of International Communication, Vol. 2.

My1510. A Review on Reporting Differences of Different Media in Communication From the Incident of Sanlu Milk Powder. [Online] Available: http://www.my1510.cn/article.php?4dea644429f2ed25

People Daily. (September 17, 2008). The number of baby sufferers of milk powder incident reached 6244, among which 158 suffered from acute renal failure. [Online] Available: http://society.people.com.cn/GB/86800/8060739.html

Sun, Caifeng (2005). Further Exploration in Theory of Media Social Responsibility. News Communication, Vol. 9.

Zhang, Ruoyu. (September 12, 2008). Milk Powder Incident: Social Alert Mechanism Disappointed the Great Trust in It. China Daily. [Online] Available: http://news.163.com/08/0912/09/4LKOPCBL00012Q9L.html

Zhou Yong. (2008). "Matthew Effect" in Internet Communication. Journal of International Communication, Vol. 3. 